\title{
West Point Foundry Preserve, Phase 1 \\ Methods
}

\section{Research Fellow:}

Lisa DuRussel

Visiting Assistant Professor

Pennsylvania State University

\section{Research Assistant:}

Aastha Singh

MSLA Candidate

Pennsylvania State University

\section{Firm Liaison:}

Daniel Yannaccone, PLA

Senior Associate

Mathews Nielsen Landscape Architects

This investigation was conducted as part of the Landscape Architecture Foundation's 2018 Case Study Investigation (CSI) program. CSI matches faculty-student research teams with design practitioners to document the benefits of exemplary high-performing landscape projects. Teams develop methods to quantify environmental, economic and social benefits and produce Case Study Briefs for LAF's Landscape Performance Series.

To cite:

DuRussel, Lisa, and Aastha Singh. "West Point Foundry Preserve Methods." The Landscape Performance Series. Landscape Architecture Foundation, 2018.

https://doi.org/10.31353/cs1361

The full case study can be found at: https://landscapeperformance.org/case-study-briefs/westpoint-foundry 


\title{
Environmental Benefits
}

\section{- Land / Land Efficiency and Preservation: Protects $32.5 \%$ of existing land within the area of work, while preserving $75 \%$ of the entire Phase 1 portion of the site.}

\begin{abstract}
Methods:
West Point Foundry Preserve was a pilot site for the Sustainable SITES program. To ensure soil protection before and during construction of any SITES project, a Vegetation and Soils Protection Zone (VSPZ) must be designated and then communicated to the project team and contractors. ${ }^{4}$ In 2006, the clients (Scenic Hudson) hired Environmental Engineers and scientists Stearns and Wheeler, LLC to prepare the Wildlife and Vegetation Inventory for the West Point Foundry Preserve site to document existing conditions as part of a feasibility study for development of natural and cultural resource interpretive programs at the site. ${ }^{5}$ The report used multiple methods over a six-month period to survey the site which included review of existing data (U.S. Geologic Survey Topographic maps, the Putnam County Soil Survey, aerial photographs of the site, as well as current and historic topographic surveys of the property, New York State Breeding Bird Atlas) and field surveys to sample for vegetation and wildlife species. ${ }^{7}$ Based on the survey methods, ecological communities were identified by the vegetation associations found within them, based on their descriptions in Ecological Communities of New York State, 2nd Edition (Edinger, et al., 2002). ${ }^{8}$
\end{abstract}

The following is an excerpt from the report:

"The western third of the West Point Foundry Preserve property is made up of Foundry Cove, a freshwater tidal bay that has been impounded by the Hudson River Line railway. Water in Foundry Cove is largely fresh; however it still receives tidal exchange from the Hudson River through a narrow channel under a railway bridge near the north end of the mouth of the Cove, but probably does not receive the full flushing it once did when the Cove was entirely open to the Hudson River. The water in Foundry Cove was not clear enough during the survey period to observe the bottom, but it was assumed that the bottom of the deeper parts of the Cove supported a freshwater subtidal aquatic bed community...Foundry Cove was also once a Superfund hazardous waste area, which was remediated in 1994. Remediation included removal and capping of hazardous materials in the east end of the Cove, followed by replanting of the area to a freshwater tidal marsh plant community which remains today. Tidal mudflats are interspersed among dense patches of emergent marsh vegetation at the east end of the Cove... The West Point Foundry site has a surprising diversity of habitat structure, ranging from estuarine aquatic habitats to freshwater stream and wetlands, to successional old fields and shrublands, to upland forest and cultural development. The diversity of ecological community provides a wide array of wildlife habitats. The proximity of the site to the suburban development and human activity of the local villages makes it a sort of wildlife oasis, especially given its immediate association with the Audubon Constitution Marsh property. No rare habitat types were identified on the West Point Foundry Preserve, but the estuarine habitats in particular are valuable breeding, foraging, and migratory stopover habitats for a wide variety of rare wildlife species...Plant biodiversity on the West Point Foundry site was reasonably high, with 131 species being represented in our samples...Sixty four species of wildlife were identified on the 
site during the survey."7

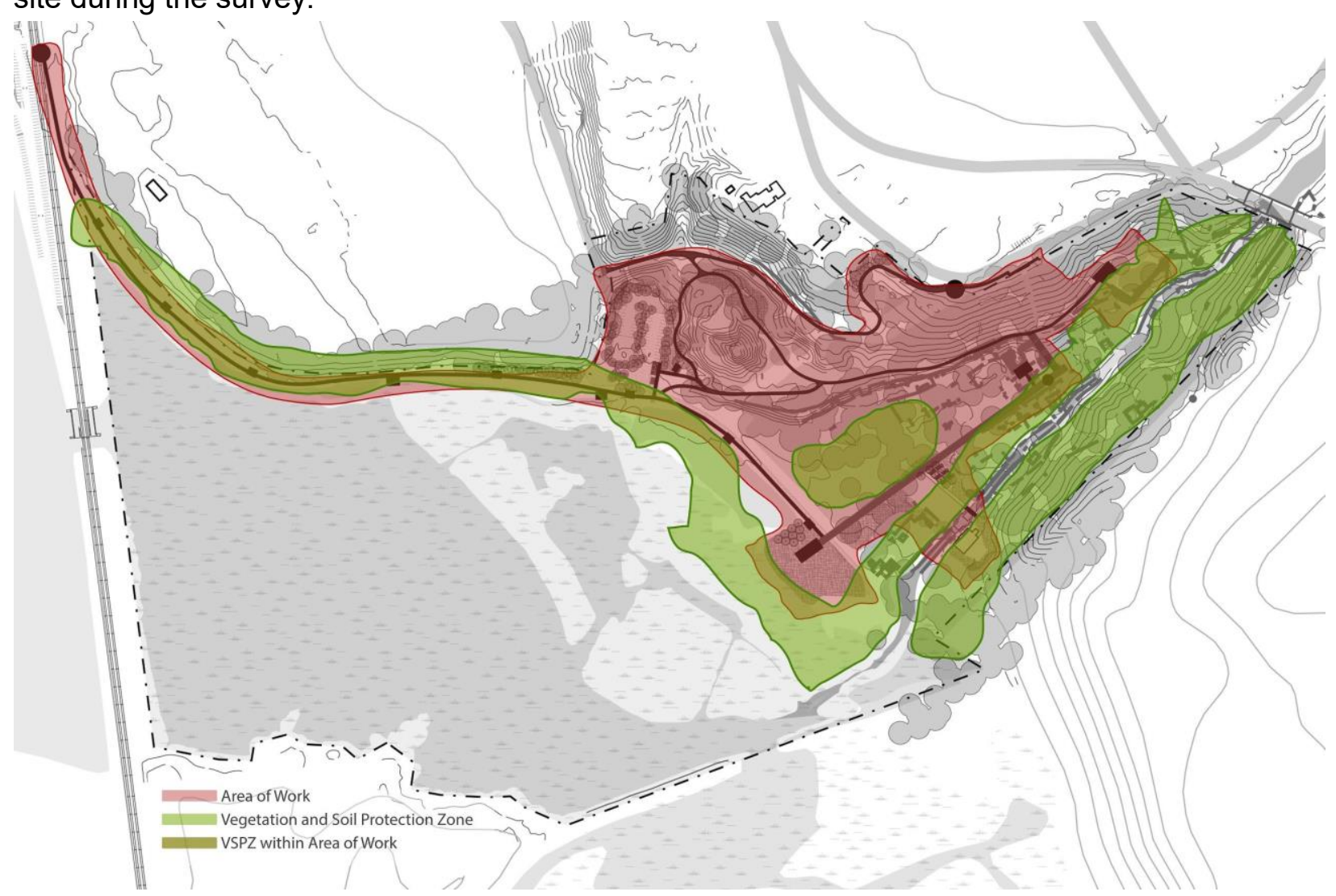

Figure 1: Site Plan with the site zoning. ${ }^{5}$

Based on the conclusions of this report, the overall VSPZ zone was identified for the site. ${ }^{4}$ One of the design goals for the landscape architects was to limit site disturbances and keep a "light touch" to maintain the ongoing ecological systems at site. Consequently, construction impacts from overall site development at WPFP were designed not to decrease the capacity of the wetlands protected by/ designated as VSPZ to support the function or capacity of the wetland to support vegetation and micro-and macro-fauna.

Previously delineated wetlands and known threatened or endangered species habitat areas (available through New York State level GIS data) were described on the "existing conditions plan" for the development of the preserve and demarcated by VSPZs and Limit of Development (LOD) areas on the "overall site plan". 5

Based on the construction drawings that were provided by the landscape architect, the area of disturbance was quantified by comparing pre and post- construction conditions. Construction documents were used to quantify the protected/ Vegetation and Soil Protection Zone (VSPZ) area vs the limit of work on AutoCAD and then compared. 
Calculations:

Percentage of VSPZ area compared to the Area of Work

(Area of Work = Limit of scope of the project)

$\begin{array}{ll}\text { Total Site Area } & =87 \text { acres. } .^{5} \\ & =3,789,720 \text { sf. } \\ & =976,503.20 \mathrm{sf} .^{5} \\ & =(976,503.21 / 3,789,720)^{*} 100 \\ & =25 \% \\ \text { Area of Work } & =75 \% \\ \text { Area of site preserved= }(100-25 \% & \\ \text { Total VSPZ area } & =909,642.58 \mathrm{sf}^{5} \\ \text { VSPZ within Area of Work } & =318,196 \mathrm{sf}^{5} \\ & =(318,196 / 976,503.20)^{*} 100 \\ & =\mathbf{3 2 . 5} \% \\ \text { Area of Disturbance } & =(100-32.5) \% \\ & =\mathbf{6 7 . 5} \%\end{array}$

Sources:

${ }^{4}$ Pieranunzi, Danielle. "SITES and Soils: A Sustainable Site Starts with Healthy Soil." National Renewable Energy Lab (NREL) Research Support Facility | SITES. July 22, 2016. Accessed July 5, 2018.

${ }^{5}$ Construction Documents, SITES certification documentation, and secondary data provided by the consulting firm, MNLA.

${ }^{6}$ The figures for Area of Work, VSPZ, and VSPZ within the Area of Work were quantified by the Research Team using ACAD, based on the zoning images received from MNLA. http://www.sustainablesites.org/sites-and-soils-sustainable-site-starts-healthy-soil.

${ }^{7}$ Stearns and Wheeler, LLC. Wildlife and Vegetation Inventory for the West Point Foundry Preserve, Village of Cold Spring, New York. Project no. 60018. 2008.

8 "Ecological Communities of New York State (Edinger Et Al. 2014)." Freshwater Wetlands Program - NYS Dept. of Environmental Conservation. Accessed June 03, 2018.

http://www.dec.ny.gov/animals/97703.html.

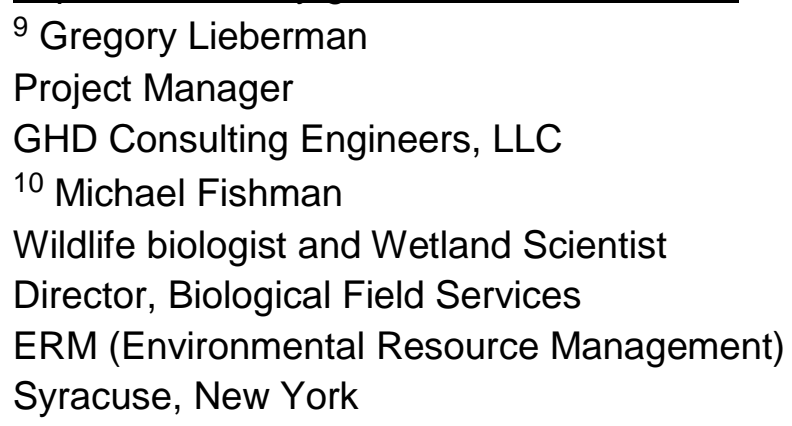


Limitations:

- Area as calculated in AutoCAD is only an estimation and is subject to human error

- The research method relies on secondary data provided by the landscape architecture consultants. The research team was not involved in data collection.

\section{- Water / Stormwater Management: Manages $90 \%$ of average annual rainfall on the area of work.}

\section{Methods:}

GHD consulting Engineers, LLC was hired by the client, Scenic Hudson, and they prepared a Stormwater Pollution Prevention Plan (SWPPP) in 2012 to meet the requirements under the State Pollutant discharge Elimination System (SPDES) General Permit for Construction Activities (GP-0-10-001). GHD Consulting Engineers, LLC were also hired to perform calculations as part of the SITES accreditation. ${ }^{11}$ In the post- development condition, the drainage patterns for most of the site remained similar due to the light touch and minimal disturbances to the existing ecology by the landscape architect. The central portion of the site, at the base of Kemble Avenue, included the most substantial land disturbance and a stormwater management system was proposed at the new parking area. Runoff from the proposed parking area was designed to be filtered via a series of bioretention systems prior to discharging to East Foundry Cove. ${ }^{5}$

The site discharges runoff to the Hudson River, which is considered a fifth order tidal water. Consequently, the client was required to construct water quality and runoff reduction measures only, whereas water quality controls were not required as per Chapter 4 of the New York State Stormwater Management Design Manual. The SWPPP was prepared using the guidance documents suggested by the New York State Department of Environmental Conservation (NYSDEC). These documents included the "New York State Stormwater Management Design Manual, 2010"12 and "New York Standards and Specifications for Erosion and Sediment Controls, $2008^{\prime 13}$ published by NYSDEC. The following is an excerpt from the report:

"According to the manual, there are five criteria used in developing/ sizing stormwater management practices: (1) water quality volume $\left(W_{v}\right)$; (2) runoff reduction volume (RRv); (3) stream channel protection volume (Cpv); (4) overbank flood control volume (Qp); and (5) extreme storm flood control volume (Qf). However, according to the Manual, the stream channel protection requirement, the overbank flood control requirement, and the extreme flood control volume requirement (Sections 4.4, 4.5 and 4.6 of the Manual, respectively) are waived from design consideration because the site discharges directly to the Hudson River, which is a fifth order tidally influenced water. Therefore, the stormwater management only considers the water quality and runoff reduction volumes. The water quality volume is designed to capture and treat 90 percent of the average annual stormwater runoff volume and is directly related to the amount of impervious area created at the site. As such, the water quality volume was calculated and utilized to size the proposed bioretention systems. In addition, various green 
infrastructure practices were incorporated into the site design to enhance infiltration of runoff and reduce the volume of stormwater leaving the site....

....The calculated WQv for the developed site was 1,800 cubic feet. However, the design provides over $\mathbf{2 , 7 0 0}$ cubic feet of runoff reduction as shown in the excerpt from the SWPP report shown below. These numbers show that the amount of runoff from the disturbed site (parking area and turnaround) during small storm events, or the $90 \%$ average annual rainfall, will be infiltrated through the bioretention basin and porous paving systems...."11

The report prepared by GHD Consulting Engineers and the calculations performed by them were referenced to quantify this benefit. ${ }^{5}$ Based on the highlighted parts of the report, the Research Team concluded that 'WPFP captures and infiltrates over $90 \%$ of the stormwater runoff from the disturbed area of the site for a 1.3-in rain event.' Detailed calculations for the WQv and RRv are shown in Appendix I at the end of this document. These calculations also show that the annual stormwater runoff for the site was calculated for the $90^{\text {th }}$ percentile annual rainfall event, which is equivalent to a 1.3-in rain event for WPFP (Appendix I).

Calculations:

The following is an excerpt from the report submitted by GHD Consulting Engineers to Ms. Rita Shaheen (Scenic Hudson): ${ }^{11}$ 


\section{Post-Construction Stormwater Management}

The stormwater management design for the WPFP consists of multiple pathways to treat water and promote infiltration and evapotranspiration. The design complies with the updated New York State Stormwater Manual which requires the use of green infrastructure to reduce the overall volume of runoff from the site.Although the work will result in a minor increase in impervious surface (gravel parking area and bus pull-off), the stormwater design includes a significant amount of green infrastructure to offset the increased volume of runoff.In addition, the stormwater design provides water quality treatment, for the $90 \%$ rainfall event or Water Quality Volume (WQv), for the parking lot and turnaround area.

The design consists of the following practices:

Linear bioretention basin - The area between the parking bays is a linear bioretention system which isdesigned to filter surface runoff through a shallow, vegetated swale. The bioretention basin will be over-excavated and backfilled with a permeable soil to promote infiltration, filtration and evapotranspiration.Larger storm events will bypass the system via the raised overflows.

Porous gravel pave - The area at the base of Kemble Avenue consists of permeable gravel pave system to limit the volume of additional runoff and promote infiltration.

Porous turf path - The walking paths from the MTA Station to the site will be retrofit with a structure turf paving promoting enhanced infiltration.

As indicated in the table below, the stormwater calculations for Runoff Reduction were completed and the project complies with NYSDEC requirements.

\begin{tabular}{|c|c|c|}
\hline Practices & RRv Provided & Remarks \\
\hline Bioretention, Including Bioswale & $730 \mathrm{cf}$ & 40 Percent of WQv to Practices \\
\hline $\begin{array}{l}\text { Porous Gravel Pave } \\
\text { System at Turnaround }\end{array}$ & $628 \mathrm{cf}$ & $\begin{array}{l}\text { Based on } 6,300 \text { Square Foot } \\
\text { Contributing Area }\end{array}$ \\
\hline Grass Pave Path & $1,435 \mathrm{cf}$ & $\begin{array}{l}\text { Based on }+3.2 \text { Acres of } \\
\text { Contributing Area }\end{array}$ \\
\hline Total Anticipated RRv* & $2,793 \mathrm{cf}$ & Exceeds Proposed WQv \\
\hline
\end{tabular}

Through these measures, we comply with the New York State standards.Specifically, we have been able to reduce, via infiltration and evapotranspiration, the entire WQv of the disturbed area via a series of green infrastructure practices.As such, we do not anticipate adverse impacts to the adjacent Foundry Cove.Full documentation is included in the project SWPPP.

Figure 2: Screenshot from the report submitted by GHD Consulting Engineers to Scenic Hudson. ${ }^{11}$

\section{Sources:}

${ }^{11}$ GHD Consulting Engineers, LLC. Stormwater Pollution Prevention Plan, West Point Foundry Preserve, Village of Cold Spring, New York. Project no. 8612105. 2012.

12 "New York State Stormwater Management Design Manual (January, 2015)." Freshwater Wetlands Program - NYS Dept. of Environmental Conservation. Accessed June 03, 2018. https://www.dec.ny.gov/docs/water pdf/swdm2015entire.pdf. 
13 "New York State Standards and Specifications for Erosion and Sediment Control (Blue Book)." Freshwater Wetlands Program - NYS Dept. of Environmental Conservation. Accessed June 03, 2018. https://www.dec.ny.gov/docs/water pdf/2016nysstanec.pdf.

Limitations:

- The research method relies on secondary calculations performed by the consulting engineers for the project. The research team was not involved in the calculations.

- While the calculations clearly state that the water quality volume exceeds the capacity to capture and treat 90 percent of the average annual stormwater runoff volume, the infiltration capacity has not been quantified in the calculations performed by the consulting engineers.

- Habitat / Habitat Creation, Preservation and Restoration: Preserves critical habitat for the Tiger Spiketail Dragonfly, a species of critical concern, by protecting $43.8 \%$ of existing habitat.

\section{Methods:}

The SITES submittal template provided for the project stated that the project contained habitat for the Tiger Spiketail (Cordulegaster erronea), a species of critical concern, and a site plan was provided outlining its location. ${ }^{5}$ The inventory and site assessments lists potential habitat for several other threatened and endangered species according to the New York State Natural Heritage Program (NYSNHP) and the New York State Breeding Bird Atlas (Atlas). ${ }^{8}$ Also, based on the surveys at site, a Vegetation and Soil Protection Zone (VSPZ) was designated on the site, as outlined on the site plan below. While the mapped species, $C$. erronea, was not listed in the wildlife and vegetation inventory provided, a brief narrative was submitted stating the species was identified by a citizen scientist and reported to the Director of Conservation Science for Scenic Hudson, who was able to include the $C$. erronea habitat in a VSPZ prior to the start of construction. ${ }^{5}$ 


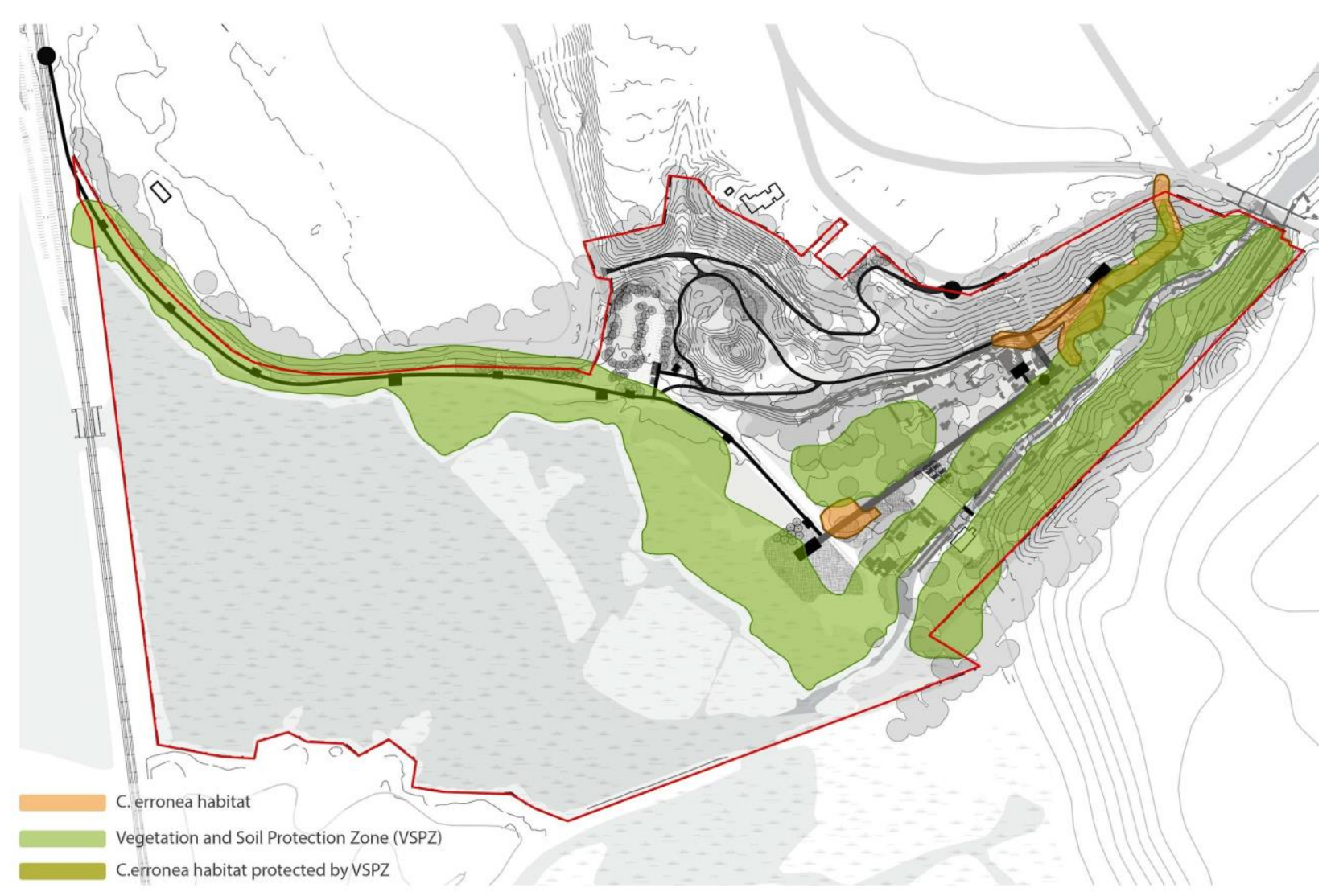

Figure 3: Site Plan showing the habitat area for Tiger Spiketail Dragonfly (C.erronea) ${ }^{5}$

\section{Calculations:}

Habitat area for C.erronea

Habitat area for C.erronea within VSPZ

$=52,116.89$ sf. $^{5}$

Percentage of $\mathrm{C}$. erronea habitat included in the VSPZ

$$
=22,809.97 \text { sf. }^{5}
$$$$
=(22,809.97 / 52116.89)^{*} 100
$$$$
=43.8 \%
$$

\section{Limitations:}

- While the Tiger Spiketail dragonfly (C.erronea) is a state-listed species by the New York Natural Heritage Program, there is no documentation that specifies it as an endangered or threatened species since it has not been listed in the wildlife and vegetation inventory for the site that is based on the New York State Natural Heritage Program (NYSNHP) and the New York State Breeding Bird Atlas (Atlas).

- The method relies on secondary data to identify and demarcate the habitat for C.erronea. The data was provided by the consulting firm wherein the habitat was determined from field observations during the pre-development surveys at site. 
- Materials and Waste / Reused and Recycled Materials: Recycled or diverted approximately 40 tons of demolition material on-site, saving an estimated $\$ 9,000$ in waste removal.

\section{Methods:}

Waste management was one of the requirements for the SITES certification. As a result, the waste generated during the construction/ demolition period was diverted from disposal in a landfill. Existing asphalt work was reclaimed on site, historic bricks were reused for landscape civil work as well as restoration of historic buildings like the Machine Shop Wall, and materials like chain link fencing and steel plates were salvaged and reused. Consequently, for this benefit, the SITES certification documentation was referred to establish the quantities of structural waste material that was reused/ diverted on site. The disposal was handled by Royal Carting Refuse where the largest dumpster available for rent for commercial use is a 30 -yard dumpster. ${ }^{14}$ The rental costs obtained from Royal Carting Refuse were used to estimate the monetary savings for reusing the waste generated on site. These savings are based on the transportation costs for the waste.

Calculations:

\begin{tabular}{|c|c|c|c|c|c|c|c|}
\hline \multicolumn{8}{|c|}{ Waste Management Log } \\
\hline Description & Quantity & Unit & Weight (Ibs) & $\begin{array}{l}\text { Weight } \\
\text { (Tons) }\end{array}$ & $\begin{array}{l}\text { Sub-totals } \\
\text { (tons) }\end{array}$ & Structural & $\begin{array}{l}\text { Road/ } \\
\text { infrastructural }\end{array}$ \\
\hline Kemble Ave - Reclamation & 350 & $\mathrm{CY}$ & 910000 & 455 & & & $\mathrm{X}$ \\
\hline Gabbion Fill- On-site & 14 & $\mathrm{CY}$ & 33600 & 16.8 & & $\mathrm{X}$ & \\
\hline Historic Bricks & 2660 & EA & 15960 & 7.98 & & $\mathrm{x}$ & \\
\hline Cut stone & 31 & Tons & 80600 & 40.3 & & $\mathrm{X}$ & \\
\hline Chain Link Fencing & 10 & Ea & 1250 & 0.625 & & $\mathrm{x}$ & \\
\hline Steel Plates (1/4" thick) & 200 & SF & 8160 & 4.08 & & $\mathrm{x}$ & \\
\hline Royal Carting Refuse- 7/31/12 & & & 12640 & 6.32 & & $\mathrm{x}$ & \\
\hline Royal Carting Refuse- $12 / 17 / 12$ & & & 8440 & 4.22 & & $x$ & \\
\hline Royal Carting Refuse- 1/2/13 & & & 10940 & 5.47 & & $\mathrm{x}$ & \\
\hline Royal Carting Refuse- 5/22/13 & & & 6800 & 3.4 & & $\mathrm{X}$ & \\
\hline Royal Carting Refuse- 6/07/13 & & & 16760 & 8.38 & & $\mathrm{x}$ & \\
\hline Royal Carting Refuse- 6/20/13 & & & 5320 & 2.66 & & $\mathrm{X}$ & \\
\hline Royal Carting Refuse- 6/26/13 & & & 18700 & 9.35 & & $\mathrm{x}$ & \\
\hline \multicolumn{4}{|l|}{ Sub-total Diverted Material (tons) } & & 524.8 & & \\
\hline \multicolumn{4}{|c|}{ Sub-total road/infrastructure materials } & & 455.0 & & \\
\hline \multicolumn{4}{|c|}{ Sub-total Refust/Waste Material: road_infrastructure } & & 0.000 & & \\
\hline \multicolumn{4}{|c|}{ Diverted $\%$ of road_infrastructure waste } & & $100 \%$ & & \\
\hline \multicolumn{4}{|l|}{ Sub-total structural materials } & & 69.8 & & \\
\hline \multicolumn{4}{|c|}{ Sub-total Refuse/Waste Material: structural } & & 39.8 & & \\
\hline \multicolumn{4}{|c|}{ Diverted\% of Structural Waste } & & $57 \%$ & & \\
\hline
\end{tabular}

Figure 4: Waste Management Log for WPFP. ${ }^{5}$

Amount of demolition waste generated during construction $=39.80$ tons $^{5}$ that was reused/ recycled on site Rental cost for a 30-yard dumpster $=\$ 895 /$ dumpster $^{14}$ Capacity of a dumpster (in tons) $=4$ tons $^{15}$ 
Number of dumpsters required to manage 39.80 tons of waste

Total money saved from demolition waste
$=39.80$ tons $/ 4$ tons

$=9.95$ (approx. 10)

$=$ No. of dumpsters required

$X$ Per unit cost of a dumpster

$=10 \times \$ 895$

$=\$ 8950$

Sources:

14 "Royal Carting Is a Leader in Residential Waste Disposal in Columbia, Dutchess, Orange, Putnam and Ulster Counties." Contact Royal Carting | (845) 896-6000 | Hopewell Junction, Amenia, Wingdale, NY. Accessed June 01, 2018. https://www.royalcarting.com/index.asp. 15 "Learn How Much It Costs to Rent a Dumpster." HomeAdvisor. Accessed July 09, 2018. https://www.homeadvisor.com/cost/cleaning-services/rent-a-dumpster/.

\section{Limitations:}

- Royal Carting provided rental cost for the year 2018. However, the rental cost for the same dumpsters during construction at the site might have been lesser.

- The cost for recycling the waste material was not taken into consideration when calculating the monetary savings.

- The quantities for the amount of waste generated were obtained from a secondary source - the SITES documentation provided by the landscape architects for the project. The research team was not involved in the gathering of this data.

\section{Social Benefits}

\section{- Cultural Preservation: Preserves the cultural heritage of the site by restoring 15 abandoned structures and important sites and refurbishing 5 industrial relics.}

\section{Methods:}

The archaeological experts performed a survey of the entire site. After careful consideration and evaluation, the Historic Properties Management Plan (HPMP) $2011^{16}$ was prepared, which documents all places of cultural relevance and outlines a management plan, following the guidelines adapted from the National Park Service's Historic American Landscape Survey (HALS): Guidelines for Historical Reports. ${ }^{17}$ After careful evaluation and site planning, buildings with maximum historic value were preserved. The following is an excerpt from the report:

\section{SITE DESCRIPTION}

\section{Historical Context}

Putnam County was one of the first communities in the country to be recognized in the White House's Preserve America initiative because of its historic sites and heritage tourism programs, 
of which several are related to West Point Foundry. WPFP and many of these historical sites are within the Local and National Register Cold Spring Historic District, as well as other National Register of Historic Places listings. They include the following:

\section{Historical and Archaeological Features}

The ruins and foundations of dozens of structures built by the WPF Association are visible on the ground surface. Others have been buried by human activities such as filling and leveling, and natural processes such as erosion and leaf litter accumulation.

The scope and scale of archaeological ruins varies from discrete locations of individual artifacts to massive building foundations and water control features such as dams and tailraces. There are ruins of docks, tramlines, and extensive retaining walls along the sloping sides of the valley that dominate the central axis of the site. In addition to industrial features, there are house ruins and deposits related to domestic habitation within WPFP....

.....Archaeological research conducted during the EPA Superfund cleanup of the East Foundry Cove confirmed that Native Americans used the WPFP area in the Precontact period. It is assumed that the environment provided an attractive setting for habitation and resource acquisition. The combination of well-drained upland soils, a nearby spring, a year-round stream, extensive marshlands, and the Hudson River made this a favorable living area. Archaeological excavations along Foundry Hill Trail recovered Precontact stone tools and waste from lithic tool production which confirmed the presence of Native Americans." 16

The HPMP Report and the designer's construction documents were reviewed and analyzed to count the number of buildings preserved. The site plan was also used to measure the length of the pathways that connect these buildings to build a narrative. Buildings that act as a destination on the site were also pulled from the West Point Foundry Tour website. ${ }^{17}$ 


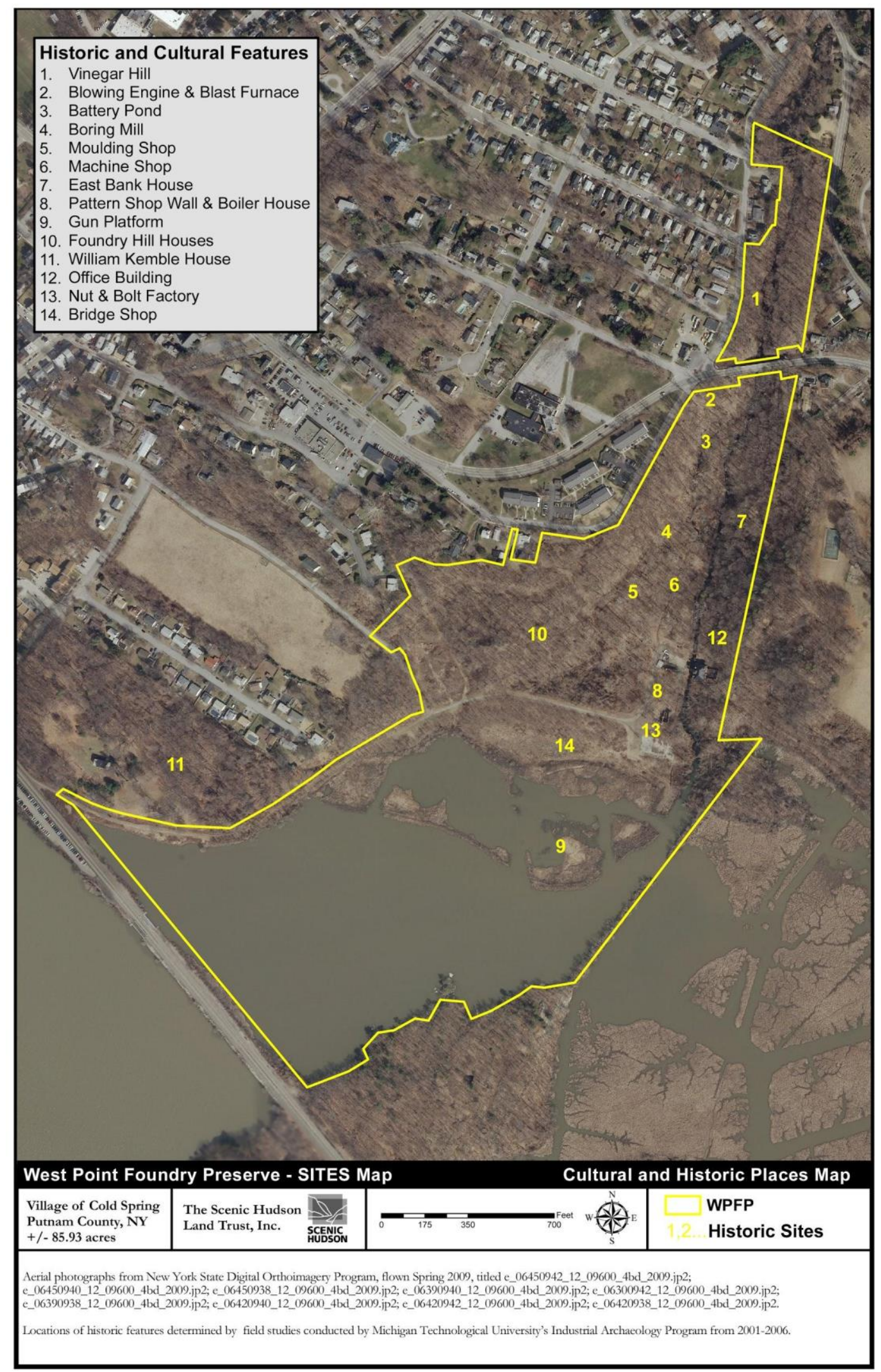

Figure 5: Survey Plan showing historic and cultural places on site. ${ }^{5}$ 


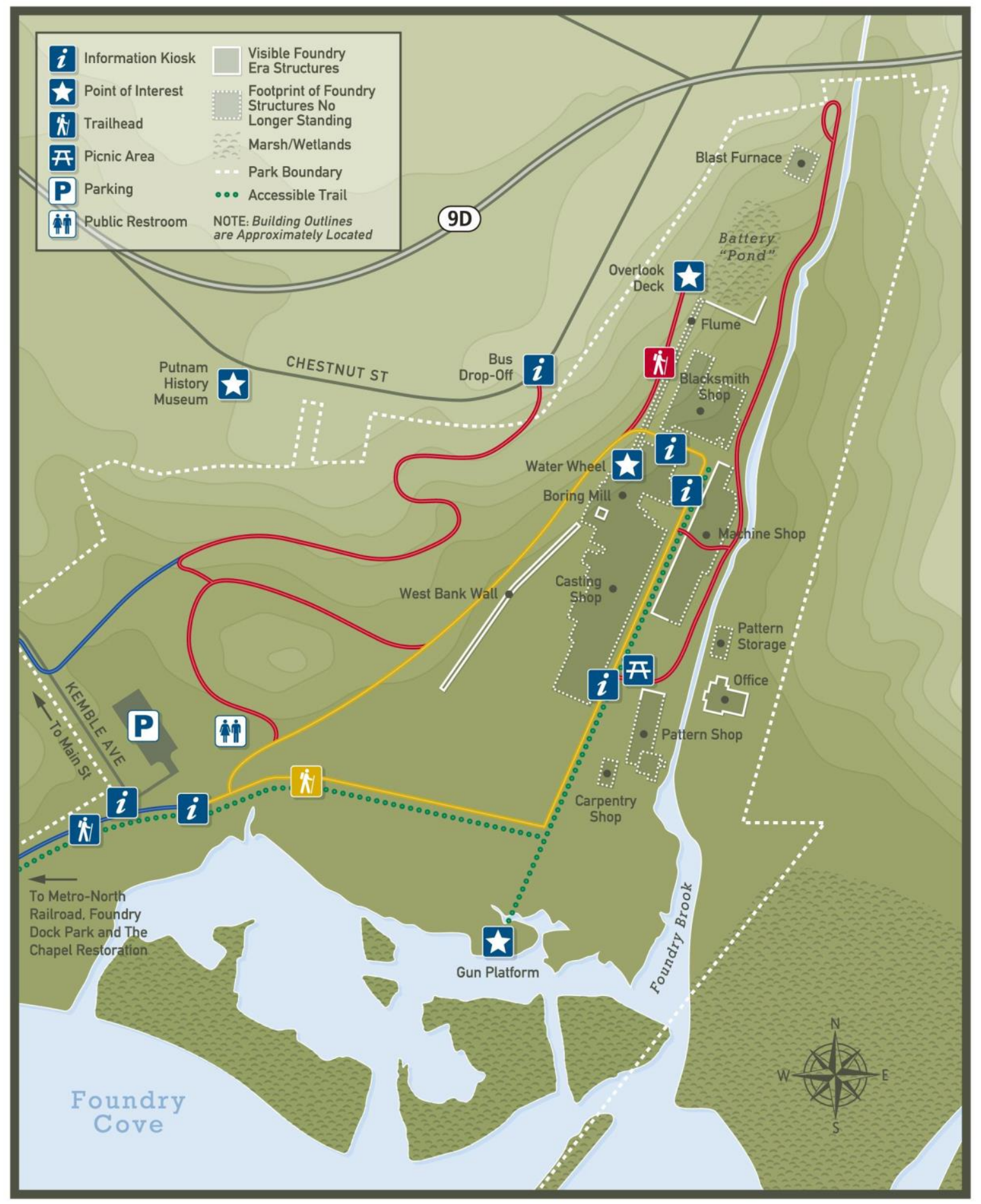

Figure 6: Site Plan showing the historic trail that reveals the cultural heritage of the site. ${ }^{5}$ 
Calculations:

Number of structures preserved $=15^{18}$

Sources:

${ }^{16}$ Historic Properties Management Plan 2011. Report. Scenic Hudson. 8-13.

17 "HALS Guidelines | HABS/HAER/HALS." National Parks Service. Accessed June 04, 2018. https://www.nps.gov/hdp/standards/HALS/HALSHistoryGuidelines.pdf.

18 "Tour Stops." West Point Foundry. Accessed June 04, 2018. http://foundrytour.org/.

Limitations:

- Since the WPFP is being developed in phases, the archaeological survey is ongoing on site. Due to that reason, the current number of restored structures may change once the uncovering and restoration is complete.

- Educational Value: Provided educational opportunities for 560 students in 2017 through educational programs in collaboration with the adjacent Putnam Museum. The educational mobile app has been used by 9,000 people since it was launched in 2013.

\section{Methods:}

Scenic Hudson collaborates with the Putnam Museum to organize educational tours of the site. ${ }^{19}$ "The Putnam History Museum collects, preserves, interprets, and presents the history of Putnam County, Philipstown, the West Point Foundry, and the Hudson Highlands. Through exhibitions, programs, and events, the museum uses its collections to engage the community with the vibrant history of our region, and to foster greater understanding of the role it has played in the growth of our nation." ${ }^{20}$ While Scenic Hudson manages the site and the preservation of the foundry buildings, the Putnam Museum has curated the documents, such as photographs, schematics, artifacts, and interactive displays as well as the Putnam County Historical Society's permanent collection of historical materials from the West Point Foundry. ${ }^{20}$ The Putnam Museum organizes educational programs for the school students in the neighborhood. In 2017, the Putnam History Museum provided WPFP tours to about 560 students. Students came from school districts in Brewster, Carmel, Yonkers, Cold Spring, Bronx, and Wappingers. ${ }^{21}$

Since the website foundrytour.org was launched in Sept 2013, almost 9,000 users have logged 12,630 sessions with the web app. The usage rate ranges from 50-100 sessions/month during the slow season to $200-450$ sessions/month during busier times. ${ }^{22}$

\section{Calculations:}

Number of students that visited the site as part of the educational tours in $2017=56022$ Number of people that use the web application since its launch $=9,00022$ 
Sources:

19 "School Groups and Tours." Putnam History Museum. Accessed June 04, 2018. http://www.putnamhistorymuseum.org/home/education/school-groups-and-tours/.

20 "Past Exhibitions." Putnam History Museum. Accessed June 04, 2018. http://www.putnamhistorymuseum.org/home/exhibitions-2/past/.

${ }^{21}$ Mark Forlow

Advisory Board Member

Putnam History Museum

22 Rita D. Shaheen

Director of Parks \& Community Engagement

Scenic Hudson, Inc.

Limitations:

- While the web application tracks the number of times users have logged in to the application, it does not take repeat users (that may be revisiting the site) into consideration.

- The data was provided by secondary sources. The research team was not involved in the data collection.

- The data for the educational program is only available for 2017. There is no data available for the years 2013 to 2016, which makes it difficult to discern any change in the number of students attending the educational programs.

- Scenic Quality and Views: Provides scenic views that are ecologically and culturally significant for the visitors as demonstrated by 1,789 tagged posts on various social media platforms.

\section{Methods:}

The client (Scenic Hudson) obtained the site in 1966 and immediately realized the archaeological significance of the site based on the discoveries in 1979 and from 1993-95 during a Superfund remediation at the adjacent Foundry Cove marsh. In 2001, the client began a long- term collaboration with Michigan Technological University-affiliated archaeologists. In 2006, amidst ongoing archaeological fieldwork, the landscape architect was hired to lead the design of a cultural landscape that invites the public to experience both its rich cultural history and its ecological legacy. The park opened in 2013. ${ }^{5}$

The client and landscape architects transformed the site into a public facility with designated pathway trails that help reveal the former Civil War artillery and ironworks, while maintaining and enhancing the site's existing ecology. By introducing trails and sculptures inspired by industrial relics found on site, the site acts as a destination for the local community to understand the historical relevance of their neighborhood. At the same time, the Foundry Brook and Foundry Cove, coupled with the adjacent tidal marsh provide an ecological backdrop for the site's functions. ${ }^{5}$ 
In the current scenario, when social media is popular medium for users to share photographs, we used that medium, and the concept of hashtags and geotagging to our advantage. This method provided us a way to tally the number of posts that indicated the scenic quality and views provided to users at the West Point Foundry Preserve. We focused on images that exhibited signs of preserved views of the pre-existing ecology of the site, the presence of historic buildings, and interpretive signage that helped reveal this cultural heritage to the users. The following photo-montage provides a reference for the attributes that were taken into consideration:

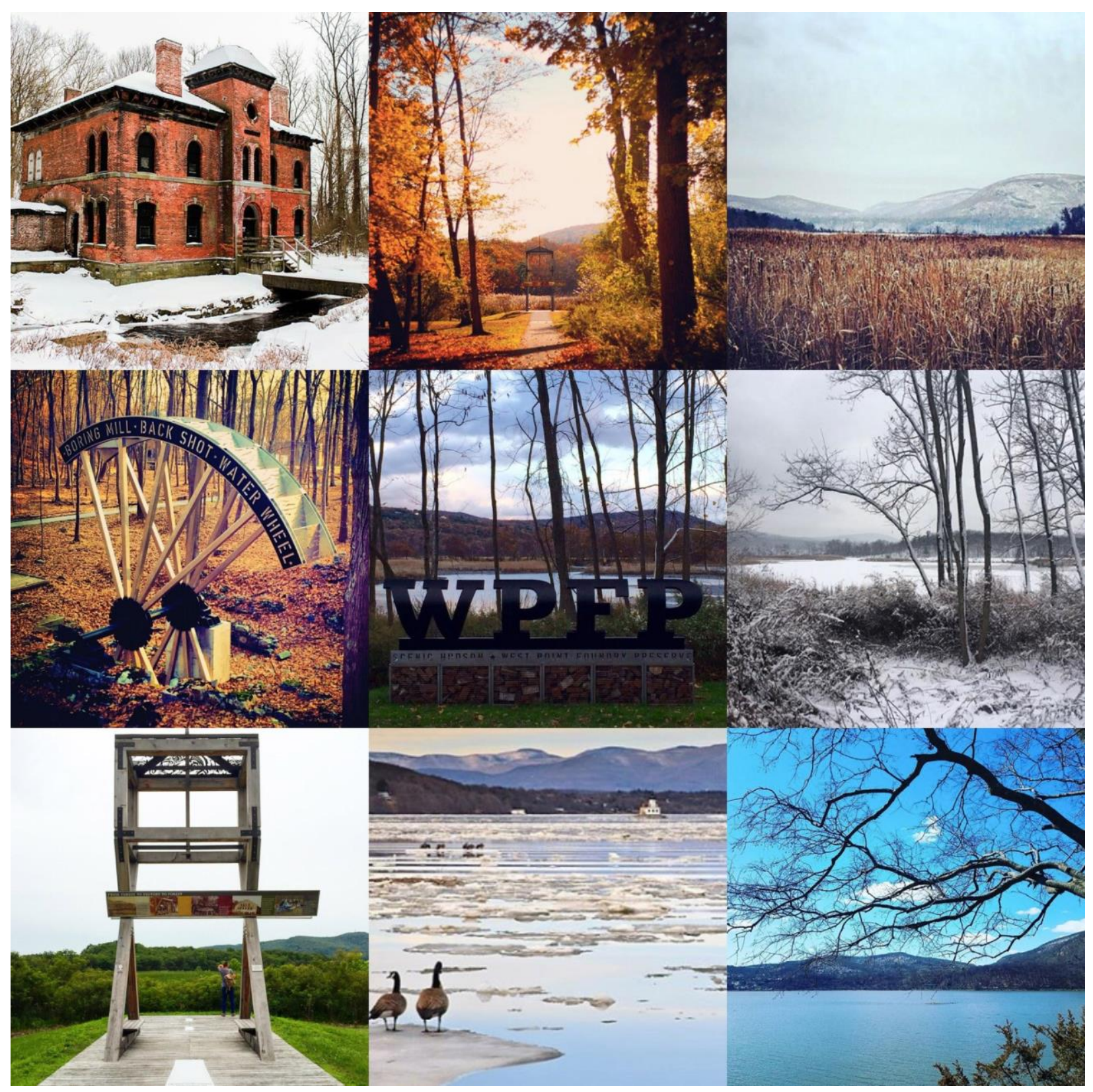

Figure 7: Photo montage of the posts from Instagram that were used as a baseline. ${ }^{26}$ 
Tagboard is an online tool that helps find all the posts across Flickr, Instagram, Facebook and Twitter that have used a specified hashtag or geotag. ${ }^{23}$ Using Tagboard, we found the number of posts on social media for the following hashtags and geotags:

\#westpointfoundry, \#westpointfoundrypreserve, \#westpointfoundryreserve, \#westpointfoundrypark

Geotag: west point foundry preserve

\section{Calculations:}

Hashtags

1. Facebook : $19+3+0+0+[448]=47024$

2. Twitter $: 12+5+0+0+[45]=62^{25}$

3. Instagram : $284+165+8+1+[452]=91026$

4. Flickr $: 142+83+14+108+[$ N.A. $]=347^{27}$

Total $=470+62+910+347=1789$

Sources:

23 https://tagboard.com/

$24 \mathrm{https}: / / \mathrm{www}$. facebook.com

$25 \mathrm{https}: / /$ www.twitter.com

${ }^{26} \mathrm{https://www.instagram.com}$

27 https://www.flickr.com

\section{Limitations:}

- Social media posts that use more than one hashtag mentioned above for the same post may have been counted multiple times, thus overestimating the number of overall social media posts.

- Some users also share the same images across multiple social media platforms, which would also result in overestimating the overall tally.

- There is a scope for human error since there is no algorithm to filter through the posts for the criteria required for this method.

\section{Cost Comparison}

The local zoning code for the village of Cold Springs stated that the toilets at WPFP were required to be flushing toilets that either tied into the village's sewer system or connected to their own septic system. However, Scenic Hudson desired to install a more environmentally sensitive toilet system that would prevent the potential leaching of contaminants into the surrounding tidal marsh. Thus, the option to install a raised septic system for the toilets was compared to the use of composting toilets. The installation of the traditional septic system on the 87-acre West Point 
Foundry Preserve site would have cost $\$ 13,850^{1}$, with an additional $\$ 350^{2}$ for annual maintenance to empty the septic tanks. The installation of composting toilets and pits on site cost a total of $\$ 85,000^{3}$, with an annual maintenance cost of $\$ 2,000 .^{3}$ In this case the less expensive option was not chosen, due to the client's desire to have the park be as low-impact and environmentally sustainable as possible.

$$
\begin{array}{ll}
\text { Total amount spent on traditional Septic System } & =\$ 13,850+\$ 350 / \text { year } \\
\text { Total amount spent on Composting Toilets } & =\$ 85,000+2,000 / \text { year }
\end{array}
$$

From an environmental perspective, while more expensive, the installation of the composting toilets helps to protect the ground water quality as it limits all the byproducts (both liquid and solid) within the composting system. On the other hand, the septic systems use a leaching field that would leach excess contaminated graywater back into the groundwater. In lieu of these factors, Scenic Hudson made a decision to install Composting Toilets at site and proposed an ordinance in the local zoning laws that allowed for the installation of Composting Toilets in certain parts of the site. These Composting toilets also act as a model unit for the local community.

\section{Sources:}

12018 Engineer's Estimate for Bid Pricing, New York City Department of Parks and Recreation. 2 "How Much Does Septic Tank Cleaning Cost? - CostHelper.com." CostHelper. Accessed July 09, 2018. http://home.costhelper.com/septic-tank-cleaning.html.

${ }^{3}$ Rita Shaheen

Director of Parks \& Community Engagement

Scenic Hudson, Inc 


\section{Appendix I: GHD Calculations for Water Quality Volume and Runoff Reduction Volume}

\begin{tabular}{|c|c|c|c|}
\hline \multirow{4}{*}{$(\mathrm{el} D \mathrm{D}$} & West Point Foundry Preserve & $11 / 29 / 2011$ & 12105 \\
\hline & Project & Date & $\mathrm{Job} \mathrm{Na}_{\mathrm{N}}$ \\
\hline & WQv Calculations & GSL & \\
\hline & Sulbject & Comp. By & Checked By \\
\hline
\end{tabular}

REQUIRED WQV TO BIORETENTION SYSTEM

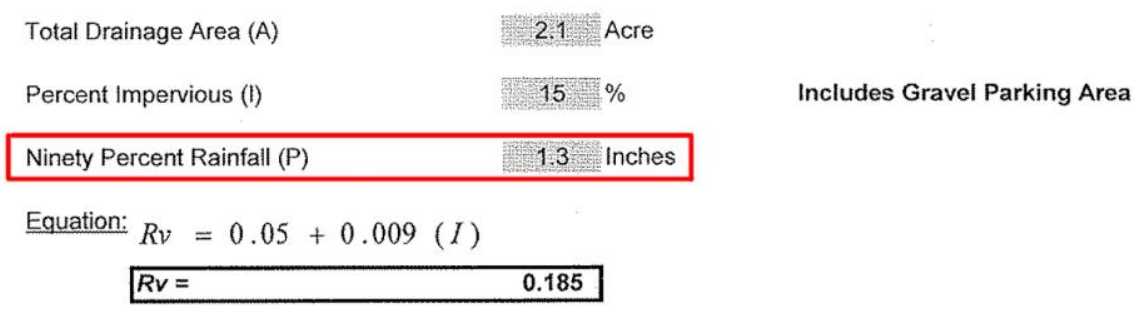

Equation: $W Q v=\frac{(P)(R v)(A)}{12}$

\begin{tabular}{ll}
\hline$Q v=$ & 0.042 \\
\end{tabular}

SIZING OF BIORETENTION

Sizing

based on

WQV of

1833 Cubic Feet

Formula: (WQv) (Df)

$A f=((k)(H f+D f)(T f))$

From NYS Design Manual Section 6.4.4

(Based on Darcy's Law)

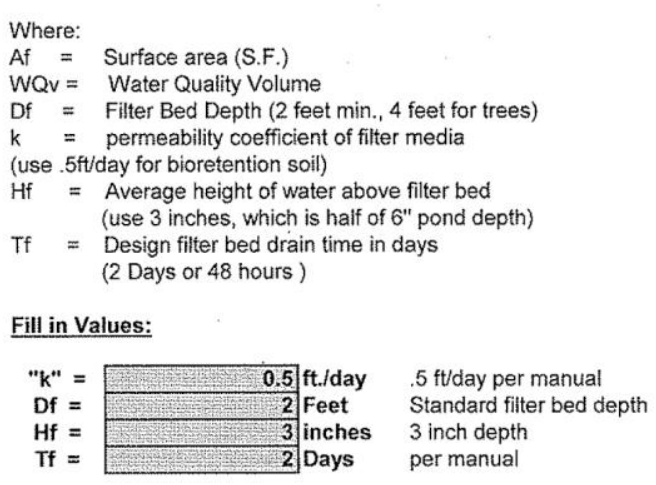

Answer:

Af $=\quad \begin{array}{r}1630 \\ \text { Square Feet Required } \\ \text { For Bioretention }\end{array}$

Bioretention No.1 $=2,030$ square feet (basin and bioswale)

Bioretention No.2 $=250$ square feet

2.280 square feet total

exceeds 1,630 sf required 


\begin{tabular}{|c|c|c|c|}
\hline \multirow{4}{*}{$(\mathrm{CH})$} & West Point Foundry Preserve & $12 / 11 / 2011$ & 12105 \\
\hline & Projoct & Date & $J 06 \mathrm{No}$ \\
\hline & $\operatorname{RRv}$ Calculations & GSL & \\
\hline & Silijiced & Comp. By & $\begin{array}{l}\text { Chedect By } \\
\text { y }\end{array}$ \\
\hline
\end{tabular}

WQV DRAINING TO POROUS PAVEMENT - Grass Pave Path

\begin{tabular}{|c|c|c|}
\hline Total Drainage Area $(A)$ & 3.2 & Acre \\
\hline $\begin{array}{l}\text { Percent Impervious (I) } \\
\qquad R v=0.05+0.009(1)\end{array}$ & 5 & $\%$ \\
\hline Ninety Percent Rainfall $(\mathrm{P})$ & 1.3 & Inches \\
\hline
\end{tabular}

Equation:

$$
W Q v=\frac{(P)(R v)(A)}{12}-0.095
$$

Equation

\begin{tabular}{|c|c|}
\hline$Q v=$ & 0.03 \\
\hline
\end{tabular}

SIZING OF POROUS PAVEMENT SUBGRADE FOR STORAGE

Formula:

$\mathrm{SV}=(\mathrm{Ap})(\mathrm{n})(\mathrm{dt})$

From NYS Design Manual

Section 5.16

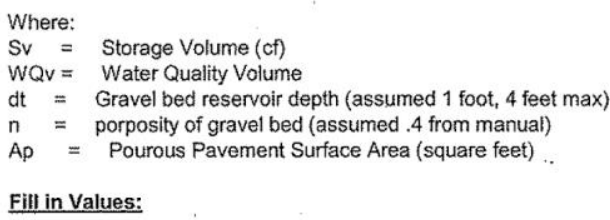

Where:

$\mathrm{SV}=$ Storage Volume (cf)

$W Q v=$ Water Quality Volume

$\mathrm{dt}=$ Gravel bed reservoir depth (assumed 1 foot, 4 feet max)

$\mathrm{n}=$ porposity of gravel bed (assumed 4 from manual)

$A p=$ Pourous Pavement Surface Area (square feet).

Fill in Values:

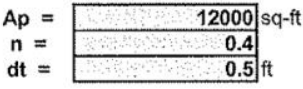

Answer:

Sv $=2400$ cubic feet yes

$2,400 \mathrm{CF}$ of available storage exceeds 1,435 sf required

G:1861121051SWPPPI12105-Water Quality Volume 


\begin{tabular}{|c|c|c|c|}
\hline \multirow{4}{*}{$\left(4^{1}\right)$} & West Point Foundry Preserve & $12 / 11 / 2011$ & 12105 \\
\hline & Project & Date & \multirow{2}{*}{$506 \mathrm{No}$} \\
\hline & RRv Calculations & GSL & \\
\hline & Subject & Comp. By & Chackest By \\
\hline
\end{tabular}

WQV DRAINING TO POROUS PAVEMENT - Gravel Pave

\begin{tabular}{|c|c|c|}
\hline Total Drainage Area (A) & 0.14 & Acre \\
\hline $\begin{array}{l}\text { Percent Impervious (I) } \\
\qquad R v=0.05+0.009(D)\end{array}$ & 100 & $\%$ \\
\hline Ninety Percent Rainfall (P) & 1.3 & Inches \\
\hline
\end{tabular}

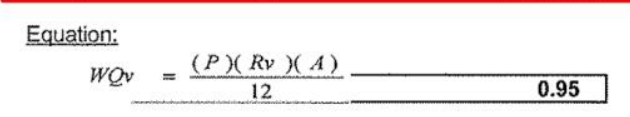

Equation

WQv $=\quad 0.014$ Acre-Feet

628 Cubic-Feet

SIZING OF POROUS PAVEMENT SUBGRADE FOR STORAGE

Formula:

$S v=(A p)(n)(d t)$

From NYS Design Manual

Section 5.16

Where:
$\mathrm{Sv}=$ Storage Volume (cf)
WQv $=$ Water Quality Volume
$\mathrm{dt}=$ Gravel bed reservoir depth (assumed 1 foot, 4 feet max)
$\mathrm{n}=$ porposity of gravel bed (assumed .4 from manual)
$\mathrm{Ap}=$ Pourous Pavement Surface Area (square feet)

Fill in Values:

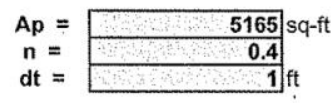

Answer:

Sv $=\quad 2066$ cubic feet

yes 